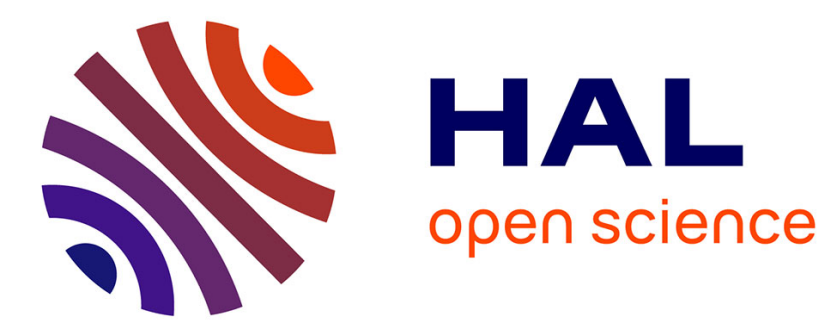

\title{
Microencapsulation of okadaic acid as a tool for studying the accumulation of dsp toxins in mussels
}

Araceli E. Rossignoli, David Fernández, Carmen P. Acosta, Juan Blanco

\section{To cite this version:}

Araceli E. Rossignoli, David Fernández, Carmen P. Acosta, Juan Blanco. Microencapsulation of okadaic acid as a tool for studying the accumulation of dsp toxins in mussels. Marine Environmental Research, 2011, 71 (1), pp.91. 10.1016/j.marenvres.2010.11.003 . hal-00658699

\section{HAL Id: hal-00658699 https://hal.science/hal-00658699}

Submitted on 11 Jan 2012

HAL is a multi-disciplinary open access archive for the deposit and dissemination of scientific research documents, whether they are published or not. The documents may come from teaching and research institutions in France or abroad, or from public or private research centers.
L'archive ouverte pluridisciplinaire HAL, est destinée au dépôt et à la diffusion de documents scientifiques de niveau recherche, publiés ou non, émanant des établissements d'enseignement et de recherche français ou étrangers, des laboratoires publics ou privés. 


\section{Accepted Manuscript}

Title: Microencapsulation of okadaic acid as a tool for studying the accumulation of dsp toxins in mussels

Authors: Araceli E. Rossignoli, David Fernández, Carmen P. Acosta, Juan Blanco

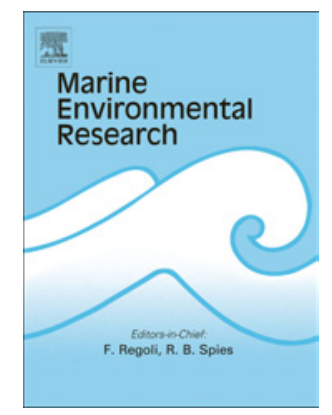

PII:

S0141-1136(10)00172-8

DOI:

10.1016/j.marenvres.2010.11.003

Reference: MERE 3485

To appear in: Marine Environmental Research

Received Date: 15 September 2010

Revised Date: 12 November 2010

Accepted Date: 17 November 2010

Please cite this article as: Rossignoli, A.E., Fernández, D., Acosta, C.P., Blanco, J. Microencapsulation of okadaic acid as a tool for studying the accumulation of dsp toxins in mussels, Marine Environmental Research (2010), doi: 10.1016/j.marenvres.2010.11.003

This is a PDF file of an unedited manuscript that has been accepted for publication. As a service to our customers we are providing this early version of the manuscript. The manuscript will undergo copyediting, typesetting, and review of the resulting proof before it is published in its final form. Please note that during the production process errors may be discovered which could affect the content, and all legal disclaimers that apply to the journal pertain. 
NOTE

\section{MICROENCAPSULATION OF OKADAIC ACID AS A TOOL FOR STUDYING THE ACCUMULATION OF DSP TOXINS IN MUSSELS}

6 Araceli E. Rossignoli ${ }^{1}$, David Fernández ${ }^{1}$, Carmen P. Acosta ${ }^{1}$, Juan Blanco ${ }^{1 *}$.

7

$8{ }^{1}$ Centro de Investigacións Mariñas (CIMA). Pedras de Corón, s/n. Apdo. 13, 36620

9 Vilanova de Arousa (Pontevedra). España

10

11 Running title: Microencapsulation of okadaic acid.

$12 *$ Corresponding author: Juan Blanco, Centro de Investigacións Mariñas (CIMA).

13 Pedras de Corón, s/n. Apdo. 13, 36620 Vilanova de Arousa (Pontevedra). Tel. +34

14 886206364; Fax: +34 886206372 E-mail: juan.blanco@ cimacoron.org 


\section{ABSTRACT}

2 The possibility and effectiveness of microencapsulation of okadaic acid (OA) in 3 gelatin acacia microcapsules has been studied. The encapsulation efficiency was $c a$.

$433 \%$. The microcapsules were shown to be very stable, not leaching more than $9 \%$ of

5 the encapsulated OA in a 20-hour period. OA from the microcapsules was absorbed by 6 the mussels very efficiently, accumulating -after 3 days of feeding and one of 7 depuration- $65 \%$ of the $\mathrm{OA}$ in microcapsules and $22 \%$ of the total OA used at the

8 beginning of the microencapsulation process. These efficiencies and the possibility of

9 encapsulating single DSP toxins and derivatives constitute a valuable tool for the study

10 of the accumulation and biotransformation of DSP toxins in bivalves.

12 Keywords: Microcapsules, okadaic acid, absorption efficiency, biotransformation, 13 mussels. 
Diarrhetic shellfish poisoning (DSP) is a syndrome caused by some polyether

2 compounds -okadaic acid (OA), analogs and derivatives- that produce diarrhoea,

3 nausea, vomiting, headache, chills and moderate to severe abdominal pain in humans

4 (Yasumoto et al., 1978). The responsible toxins are produced by several species of

5 dinoflagellates belonging to the genus Dinophysis and Prorocentrum (Yasumoto et al.

6 1980, Murakami et al., 1982; reviewed in Blanco et al., 2005) and are accumulated by

7 shellfish that feed on these species. DSP toxicity probably has the highest impact on

8 bivalve aquaculture, as it is frequently found in areas in which that activity is intense,

9 such as Galicia (Spain) or southern Chile.

10 Mitigating the consequences of these blooms requires understanding the

11 mechanisms involved in the absorption, elimination and transformation of this group of

12 toxins by the bivalves. Experimental approaches are hampered by the difficulty of

13 obtaining cultures of DSP-producing organisms and even when those are obtained, the

14 cells usually contain a complex mixture of toxins and toxin derivatives that makes

15 interpretation of the results difficult.

16 In order to supply the bivalves with food containing individual toxins or

17 derivatives, we have studied the possibility and the effectiveness of microencapsulation

18 of okadaic acid in gelatin-acacia microcapsules.

19 To obtain okadaic acid, naturally contaminated mussels were dissected, weighed

20 and their digestive glands homogenized in methanol in a proportion of $1 \mathrm{~g}$ of tissue (4

$21 \mathrm{~mL}$ of extraction solvent), with an Ultraturrax $\mathrm{T} 25$ Basic (IKA). The obtained

22 homogenate was centrifuged at $48000 \mathrm{~g}$ for $20 \mathrm{~min}$ to clarify the solution (Beckman

23 Avanti J-25). The extract was diluted to 50\% methanol and subjected to liquid -liquid

24 partitions with hexane and dichlorometane. The absence of conjugated forms (acyl

25 derivatives or diol-esters) in the extract was checked by means of alkaline hydrolisis, 
1 that transforms them to free OA. The dichloromethane fraction was evaporated to

2 dryness and redissolved in $0.5 \mathrm{~mL}$ of olive oil. Aliquots of $0.25 \mathrm{~mL}$ were used to

3 quantify $\mathrm{OA}$ in the extract and to be microencapsulated respectively

4 Gelatin-acacia microencapsulation was based on the complex coacervation method 5 used by Planas et al. (1990) but with slight modifications (Figure 1). Once the 6 microcapsules had been produced they were washed by allowing them to decant,

7 removing supernatant water, adding new water and shaking the suspension gently. This 8 operation was repeated each day during the experiment in order to avoid lump 9 formation.

10 The encapsulation efficiency was quantified by the proportion of OA that was 11 successfully encapsulated. OA contained in the microcapsules was quantified by 12 extraction of approx. $1 \mathrm{~g}$ of microcapsules, with methanol $100 \%(1: 4, \mathrm{v} / \mathrm{v})$ and 13 clarification by centrifugation for $20 \mathrm{~min}$. at $48000 \mathrm{~g}$.

14 The capability of the microcapsules to retain the toxins when they are suspended 15 in seawater was also studied. Microcapsules were placed in seawater and samples of this 16 water were taken at different times $(0,1,2,3,4$ and $20 \mathrm{~h})$. An initial blank of the 17 seawater was also analysed. OA was extracted from the water by liquid-liquid partition with dichloromethane, evaporation of the organic fraction, and resuspension in $100 \%$. 19 methanol

Finally, we have shown that the toxins from microcapsules can be absorbed by 21 mussels and they can be traced after being fed. OA-containing microcapsules were fed 22 to two groups of six mussels obtained from the same batch which contained low levels 23 of toxins (Table I). The mussels were placed in a beaker and were fed with a diet 24 constituted by $10 \mathrm{~mL}$ of the microcapsules suspension (approximately $1 \mathrm{~g}$ of 25 microcapsules) plus $25 \mathrm{~mL}$ of a culture of the microalgae Tetraselmis sp. $\left(3 \times 10^{6}\right.$ 
1 cels $\cdot \mathrm{mL}^{-1}$ ) plus $0.05 \mathrm{~g}$ of clay. The food was supplied twice a day during 3 days. After

2 the third day of feeding, mussels were maintained without food for an additional day, in

3 order to remove most undigested food from the digestive system before analysis. This

4 step was needed because very likely not all microcapsules are digested and, if they are

5 not removed from the gut, the toxin they contain would be measured jointly with the

6 absorbed one thus making it impossible to discriminate the absorbed from the ingested

7 toxin. Furthermore, feces were collected from the bottom of the beaker every day and

8 pooled the last day of the experiment. At the end, the digestive glands were

9 homogenized in methanol $(100 \%)$ in a proportion of $1: 4, \mathrm{w}: \mathrm{v}$, with an Ultraturrax T 25

10 Basic (IKA) and the homogenate obtained was centrifuged at $48000 \mathrm{~g}$ for $20 \mathrm{~min}$ to

11 clarify the solution. This extract was analyzed to quantify free OA. In order to quantify

12 the total amount of toxin (OA and its conjugated forms $(\mathrm{CF})$ ) the methanolic extracts

13 were subjected to an alkaline hydrolysis (after Vale and Sampayo, 1999, but using a

14 temperature of $80^{\circ} \mathrm{C}$ ). The extracts were desalted and partially cleaned with polymeric

15 reverse-phase SPE cartridges Strata $X(60 \mathrm{mg} / 3 \mathrm{~mL})$ (Phenomenex). Feces were

16 subjected to the same procedure, with the exception that the proportion of methanol

17 added to extract the toxins was $4 \mathrm{~mL}$ of methanol per $\mathrm{mL}$ of feces, instead of per gram

18 as in digestive glands.

19 OA concentration in each extract was determined by HPLC-ESI-MS with a

20 Thermo LCQ-Deca XPplus ion trap mass spectrometer with electrospray ionization

21 coupled to a Thermo Surveyor HPLC. The chromatographic separation was carried out

22 using the method of Quilliam (2003) slightly modified to adapt it to a fused core column

23 (HALO C8 50x2.1 mm $2.7 \mu \mathrm{m}$ ). The two mobile phases were: $\mathrm{A}=\mathrm{H}_{2} \mathrm{O}: \mathrm{F}(95: 5)$ and $\mathrm{B}=$

$24 \mathrm{CH}_{3} \mathrm{CN}$ : $\mathrm{F}(95: 5)$, where $\mathrm{F}$ was $40 \mathrm{mM}$ ammonium formate and $1 \mathrm{M}$ formic acid in

25 water. The gradient program went from $5 \%$ to $100 \%$ B over $5 \mathrm{~min}$, hold for $5 \mathrm{~min}$ and 
1 then re-equilibrate at the starting conditions for $5 \mathrm{~min}$ prior to the next injection. Flow

2 rate was $400 \mu \mathrm{L} \mathrm{min}^{-1}$ and injection volume $5 \mu \mathrm{L}$. The mass spectrometer was operated

3 in negative ionization mode and SIM (selected ion monitoring) for $803.5 \mathrm{~m} / \mathrm{z}$.

4 Quantification of the OA was carried out by comparing the resulting response with that

5 of the reference materials (OA-1b) obtained from IMB - NRC, Canadá. The presence of

6 matrix effect was checked by serial dilutions of the samples and corrected when needed

7 by using the results obtained with the largest dilution.

8 Some modifications to the microencapsulation technique of Planas et al. (1990)

9 were made in order to adapt the microcapsule size to the requirements of mussels. In

10 this sense we have used a $\mathrm{pH}$ of 7 for the step of mixture of colloids and of 4.2 for the

11 emulsification, obtaining microcapsules with a diameter about $50 \mu \mathrm{m}$. Also a

12 homogenization with Ultraturrax at $24000 \mathrm{rpm}$ (instead of the sonication of the original

13 technique) was introduced to favor a correct mixture between the OA-olive oil and the 14 acacia solution.

The efficiencies of encapsulation of the oils (olive and cod liver oil) were always

16 high and similar to the ones obtained by Planas et al. (1990) encapsulating cod liver oil

17 (50 to $85 \%)$ or by Knauer and Southgate (1997) encapsulating lipids (ca. 80\%).

18 However the encapsulating efficiency of OA was lower, ranging from 33 to $53 \%$. This

19 difference is probably due the partially hydrophilic nature of OA, (its partition

20 coefficient between water and olive oil which is roughly 0.3 , as we have estimated in a

21 preliminary experiment in which ca. $30 \%$ of okadaic acid remained in water after a 1:1

22 water:olive oil liquid-liquid partition).

23 The stability of the microcapsules in seawater was good, as the OA they contain

24 did not leach substantially. Only about $8.5 \%$ of the toxin contained in the microcapsules

25 was lost as soon as they were suspended in seawater ( 0 hours), probably due to an 
1 insufficient washing, and no significant loss (c.a. $0.5 \%$ ) could be detected after that

2 time. Planas et al. (1990) found a similar leaching percentage for cod liver oil but during

3 an 8-hour period notwithstanding, with no noticeable loss at 0 hours.

5 cycle no suspension in the water was apparent and no pseudofeces detected, indicating

6 that all the food supplied was ingested. At the end of the experiment the six mussels had

7 increased their total toxin content (OA free + OA Conjugated forms) in the digestive

8 gland (DG) by $1.857 \mu \mathrm{g}$ (Table 1). This accumulation by the mussels represents $63 \%$ of

9 the microencapsulated toxin and $22 \%$ of the initial toxin amount. A large proportion of

10 the toxin is therefore lost but enough of it was retained by mussel as to consider the

11 technique useful to study toxin accumulation and bio-transformation. In feces, only a

12 small percentage of free OA was found and most was found as conjugated forms. From

13 this proportion of free OA an absorption efficiency higher than $88 \%$ could be estimated

14 (assuming that the free okadaic acid is not transformed in the gut, and that consequently

15 the free OA found in feces comes from the non-absorbed toxin plus the first absorbed

16 and then excreted free toxin).

It can be concluded that microencapsulation is a viable way of supplying toxic

18 food for studies of accumulation and biotransformation of biotoxins in bivalves.

19 Mussels feed well on gelatin-acacia microcapsules if they are mixed with microalgae.

20 The microencapsulated toxins can be readily absorbed allowing a substantial increase in

21 toxin concentrations of the mussels in a few days.

It seems clear that this technique is more feasible for studying the

23 biotransformation and the mechanisms involved in accumulation than using Dinophysis

24 or Prorocentrum cultures and also than the study of naturally intoxicated populations.

25 In all cases because the complexity of the toxin mixture could be controlled and 
1 simplified. In the case of Dinophysis cultures, because the AO producing species in this

2 genus have complex nutritional requirements. D. acuminata, for example, requires (as

3 far as we know presently) a partially photosynthetic ciliate (Myrionecta rubra) as prey.

4 The ciliate must obtain the chloroplasts form a cryptophyte (usually Teleaulax) (Park

5 et al. 2006). Culturing this species requires consequently three steps (one for each

6 species) that should be carefully synchronized. That is an expensive and time

7 consuming process, which is additionally prone to fail due to contamination of the final

8 Dinophysis culture with the cryptophytes. In relation to Prorocentrum, using

9 microcapsules has advantages because the species in this genus are inefficiently

10 digested by mussels, and (and perhaps because of), at least some of them produce a

11 number of bioactive compounds (Cruz et al., 2008; Napolitano et al., 2009; Napolitano

12 et al., 2010). Microcapsules can be used to supply mussels with individual DSP toxins

13 derivatives that have lower polarity than okadaic acid, such as 7-O-acyl derivatives or

14 diol esters, but its use with more polar derivatives, such as "DTX4" and "DTX5",

15 should be additionally evaluated. 


\section{ACKNOWLEDGEMENTS}

2

This work was funded by the Consellería de Innovación e Industria through the

3 collaboration agreement EPITOX. The work of Araceli Escudeiro Rossignoli was

4 funded by a grant of the Consellería de Pesca e Asuntos Marítimos, Xunta de Galicia, in

5 the framework of the Programa de Recursos Humanos of the PGDIT 2006-2010. We

6 thank H. Martín for their technical assistance and the Departments of Sampling and

7 Biotoxins of the Instituto Tecnolóxico para o Control do Medio Mariño de Galicia for 8 providing the experimental mussels. 


\section{REFERENCES}

2

3 Blanco, J., Moroño, A., Fernández, M. L., 2005. Toxic episodes in shellfish, produced

4 by lipophilic phycotoxins: An overview. Revista Galega dos Recursos Mariños 5 (Monog.) $\quad 1, \quad 1-70 . \quad$ [Online] $\quad$ http://www.recmar6 galicia.org/pdf/BlancoetalRGRMMonog1_2005.pdf

7

8 Cruz, P.G., Fernández, J.J., Norte, M., Daranas, A.H., 2008. Belizeanic acid: A potent

9 protein phosphatase 1 inhibitor belonging to the okadaic acid class, with an unusual 10 skeleton. Chemistry, A European Journal 14, 6948-6956.

12 Knauer, J., Southgate, P.C., 1997. Assimilation of gelatin-acacia microencapsulated 13 lipid by Pacific oyster (Crassostrea gigas) spat. Aquaculture 153, 291-300.

15 Murakami, Y., Oshima, Y., Yasumoto, T., 1982. Identification of okadaic acid as a 16 toxic component of a marine dinoflagellate Prorocentrum lima. Bull. Jpn. Soc. Sci. 17 Fish. 48(1), 69-72.

19 Napolitano, J.G., Norte, M., Padron, J.M., Fernández, J.J., Daranas, A.H., 2009.

20 Belizeanolide, a cytotoxic macrolide from the dinoflagellate Prorocentrum belizeanum.

21 Angewandte Chemie-International Edition 48, 796-799. 
1 Napolitano, J.G., Norte, M., Fernández, J.J., Daranas, A.H., 2010. Corozalic acid:

2 A key okadaic acid biosynthetic precursor with phosphatase inhibition activity.

3 Chemistry, A European Journal 16 (38), 11576-11579.

4

5 Park, M. G., Kim, S., Kim, H. S., Myung, G., Kang, Y. G., \& Yih, W., 2006. First

6 Successful Culture of the Marine Dinoflagellate Dinophysis acuminata. Aquatic

$7 \quad$ Microbial Ecology, 45(2), 101-106.

9 Planas, M., Fernández-Reiríz, M.J., Ferreiro, M.J., Labarta, U., 1990. Effect of selected 10 variables on the preparation of gelatin-acacia microcapsules for aquaculture. Aquacult. 11 Eng. 9(5), 329-341.

13 Quilliam, M.A., 2003. Chemical method for lipophilic shellfish toxins. In: Hallegraeff, 14 G.M., Anderson, D.M., Cembella, A.D. (Eds.), Manual on Harmful Marine Microalgae. 15 UNESCO Publishing, Paris, pp. 211-245.

16

17 Vale, P. and Sampayo, M.A., 1999. Esters of okadaic acid and dinophysistoxin-2 in 18 Portuguese bivalves related to human poisonings. Toxicon 37 (8), 1109-1121.

20 Yasumoto, T., Oshima, Y., Yamaguchi, M., 1978. Occurrence of a new type of shellfish 21 poisoning in the Tohoku district. Bull. Jpn. Soc. Sci. Fish. 44, 1249-1255.

23 Yasumoto, T., Oshima, Y., Sugawara, W., Fukoyo, Y., Oguri, H., Igarza, T., Fujita, N., 24 1980. Identification of Dinophysis fortii as the causative organism of diarrhetic shellfish 25 poisoning. Bull. Jpn. Soc. Sci. Fish. 46(11), 1405-1411. 


\section{1}

2

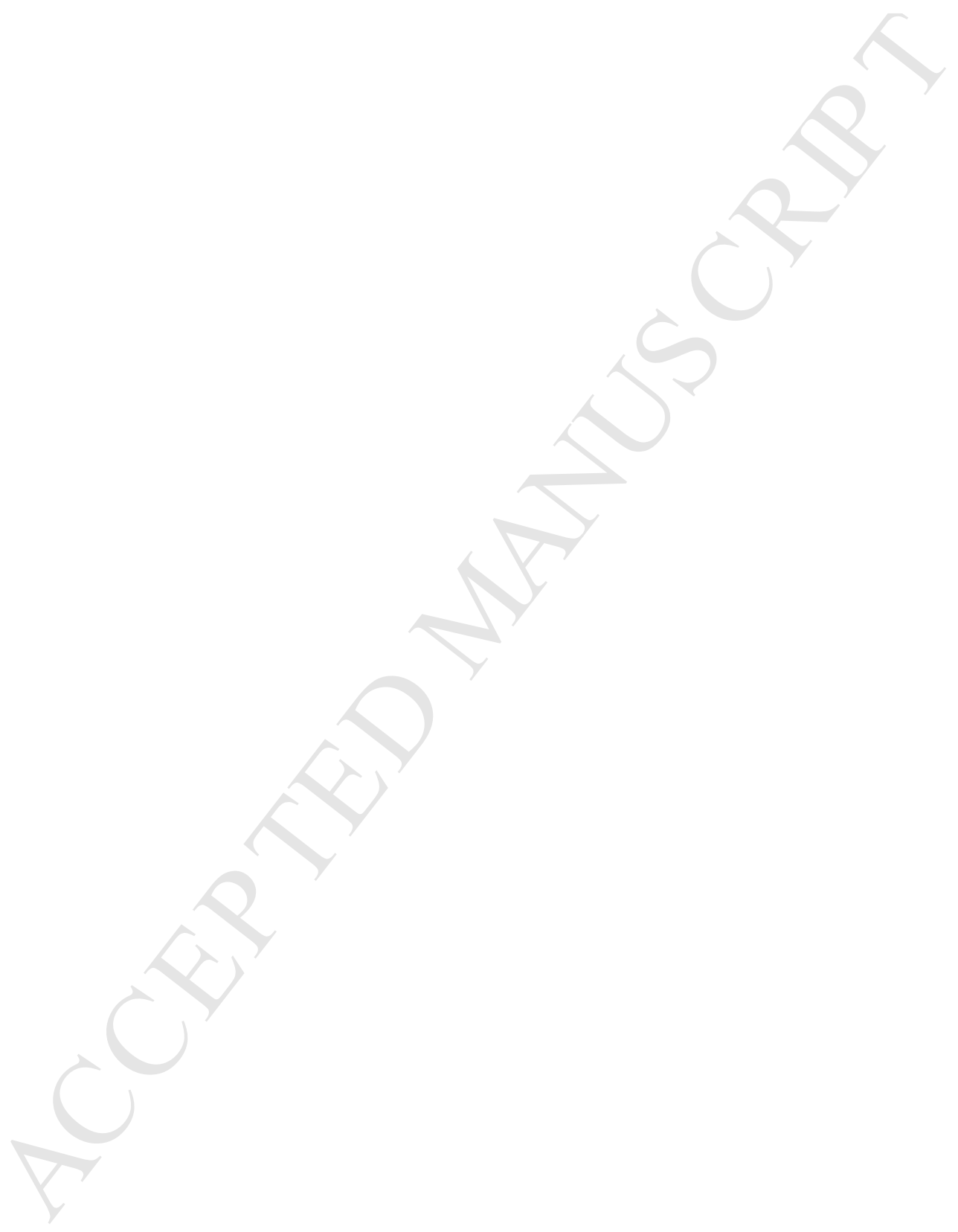




\section{FIGURE AND TABLE CAPTIONS}

2

3 Figure 1: Schematic diagram of the preparation of okadaic acid gelatin-acacia 4 coacervate microcapsules (Partially from Planas et al., 1990).

5

6 Table 1: Content of okadaic acid (OA) and their conjugated forms (CF) in the digestive 7 gland of mussels and feces at the beginning and the end of the experiment.

8 DG $=$ digestive gland; Day $1=$ the first day that the mussels were fed. Day $4=$ the day 9 after the last feeding. 
$0.5 \mathrm{~g}$ of Acacia dissolved in $50 \mathrm{~mL}$ of water $40^{\circ} \mathrm{C}$$$
\text { of water } 40^{\circ} \mathrm{C}
$$

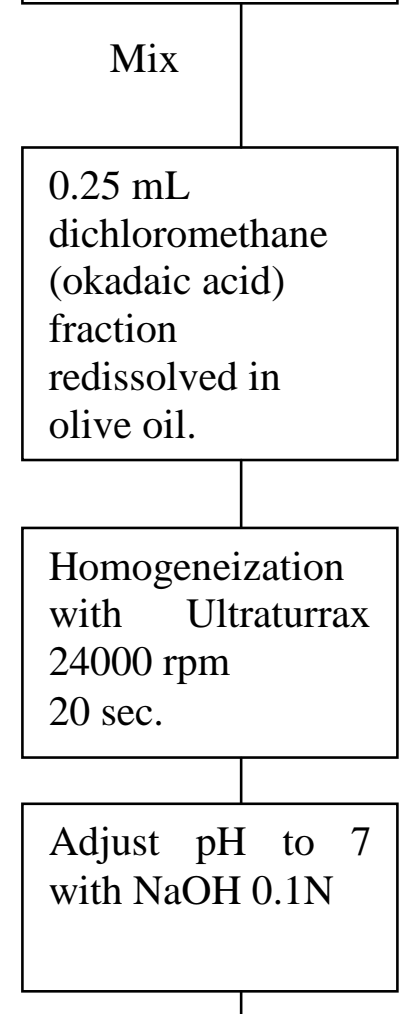

$0.5 \mathrm{~g}$ of Gelatin dissolved in $50 \mathrm{~mL}$ of water $40^{\circ} \mathrm{C}$

\section{Emulsify}

Adjust $\mathrm{pH}$ to 7 with $\mathrm{NaOH} 0.1 \mathrm{~N}$

\section{(Magnetic stirrer)}

Stirring rate: $250 \mathrm{rpm}$. $30 \mathrm{sec}$.

Adjust $\mathrm{pH}$ to 4.2 with $\mathrm{HCl} 0.1 \mathrm{~N}$.

Stirring rate: $250 \mathrm{rpm}$

Gelation of coacervates by cooling in an ice bath for 20 minutes.

Stirring rate: $100 \mathrm{rpm}$

Adjust $\mathrm{pH}$ to 9.0 with $\mathrm{NaOH} 0.1 \mathrm{~N}$

Agitate for 30 minutes Stirring rate: $100 \mathrm{rpm}$

Let stand the mixture for 2 hours at $4^{\circ} \mathrm{C}$ 
Type of Toxin $\quad$ Toxin in Day $1 \quad$ Toxin Day 4 (T0) $(\mu \mathrm{g})$
(TF) ( $\mu \mathrm{g})$
Toxin increase

$(\mu \mathrm{g})$

\begin{tabular}{|c|c|c|c|c|}
\hline \multirow{2}{*}{ Mussels } & OA & 0.4750 & 0.7802 & 0.3052 \\
\hline & $\mathrm{CF}+\mathrm{OA}$ & 1.0973 & 2.9545 & 1.8572 \\
\hline \multirow{2}{*}{ Feces } & OA & Not sampled & 0.1663 & - \\
\hline & $\mathrm{CF}+\mathrm{OA}$ & Not sampled & 1.3706 & - \\
\hline
\end{tabular}

